\title{
LOCATION DRIVERS, GOVERNANCE MODELS AND PERFORMANCE IN SERVICE OFFSHORING
}

\author{
Federico Caniato* \\ (federico.caniato@polimi.it) \\ Stefano Elia* \\ (stefano.elia@polimi.it) \\ Davide Luzzini* \\ (davide.luzzini@polimi.it) \\ Lucia Piscitello* \\ (lucia.piscitello@polimi.it) \\ Stefano Ronchi* \\ (stefano.ronchi@polimi.it)
}

*Department of Management, Economics and Industrial Engineering - Politecnico di Milano Piazza Leonardo da Vinci, 32 - 20133 MILANO.

Please Cite the paper as follows:

Caniato, F., Elia, S., Luzzini, D., Piscitello, L., \& Ronchi, S. (2015). Location drivers, governance model and performance in service offshoring. International Journal of Production Economics, 163, 189-199.

https://doi.org/10.1016/j.ijpe.2014.09.011 


\section{ABSTRACT}

The present paper deals with the performance implications of service activities offshoring, meant as the delocalization of business services in foreign countries. Data are coming from the Offshoring Research Network (ORN) and were processed through an Exploratory Factor Analysis to aggregate variables first and then through a two-stage approach à la Heckman in order to control for the potential endogeneity problem arising from the self-selection bias in the regression models. Through these models we investigate the relationship between the motivations leading to choose a specific offshoring location (i.e. strategic location drivers: low cost, resources availability, cultural proximity, and the presence of local networks) and both operational and strategic performance of the offshoring firm. Provided that offshoring may occur either through a wholly-owned subsidiary (captive offshoring) or by outsourcing the service activity (offshore outsourcing), we provide a contribution by investigating the moderating role of the governance model on the relationship between location drivers and performance. Our results show that both operational and strategic performance are affected positively by low cost and resources availability, while local networks has a positive impact on strategic performance and negative one on operational performance. Moreover, offshore outsourcing strengthens the effect of resources availability and local networks on operational performance, as well the effect of cultural proximity and resource availability on strategic performance, while captive offshoring strengthens the effect of low cost and local networks on strategic performance.

Keywords: location drivers, offshoring, governance model, performance 


\section{INTRODUCTION}

Offshoring is conceptualized as sourcing of activities outside a firm's home country for purposes of serving home country or global operational requirements (Massini et al., 2010). The term is also used to refer to several control situations, ranging from international sourcing and purchasing (Kotabe, 1990) and external to the firm's boundaries (so called offshore outsourcing), to the operation of wholly owned operations, i.e. offshore activities located within the firm’s boundaries, so called captive offshoring (Mudambi and Venzin, 2010).

While historically the term offshoring has referred implicitly to activities pertaining to manufacturing production, the recent wave of offshoring concerns administrative and technical services. Offshoring of business services has enormously increased in the last decade (e.g. Doh, 2005; Dossani and Kenney, 2005; Kotabe et al., 2009; Luzzini and Ronchi, 2011; Lewin and Volberda, 2011). However, outcomes are far from optimum, given the level of complexity determined by location characteristics, types of tasks, choice of suppliers and so on, making implications of professional services outsourcing more problematic than manufacturing outsourcing (Ellram et al., 2008). A few cases even show firms that are back-shoring tasks such ad Dell or Lehman Brothers - to home/closer countries (Aron and Singh 2005; Bunyaratavej et al., 2007; Ren and Zhou, 2008). Not surprisingly, several scholars call for more research on offshoring of services (e.g. Roth and Menor, 2003). Therefore, we believe it is worth investigating into this turbulent matter in order to, on the one hand, enrich the empirical evidence in research and, on the other hand, provide managers with useful guidelines.

Scholars measure the offshoring success through several performance dimensions. Much of the traditional literature on offshoring emphasizes its cost-saving motivations while recent discussions highlights more articulated motivations driving firms’ offshoring decisions, including the access to human resources and talent, knowledge and new technologies (Kedia and Lahiri, 2007; Lewin et al., 2009). Thus, location choices also change accordingly. In fact, 
as the choice of offshore location can also determine success of the offshoring implementations (Aron and Singh, 2005; Jensen and Pedersen, 2011), location drivers are not only related to low costs, but also to strategic resources, quality and infrastructure and so on (Massini et al., 2010). The question is how do different location drivers affect the achievement of different types of offshoring performance.

However, not only location drivers might directly affect offshoring performance, they also interact with the sourcing strategy (i.e., the governance model) adopted in determining performances (Murray, Kotabe and Wildt, 1995). In fact, several studies on offshore outsourcing already testify that outsourcing and offshoring appears nowadays as intertwined phenomena (Hatonen and Eriksson, 2009; Contractor et al., 2010; Mudambi and Venzin, 2010).

Therefore, the aim of this study is twofold. Firstly, we intend to clarify which location drivers impact on which types of offshoring performance. Secondly, we investigate the role played by the governance model adopted when firms decide to offshore.

We test our hypotheses through an empirical analysis that relies on data from the Offshoring Research Network (ORN) survey, using a sample of 142 data collected in 2009.

The paper is organized as follows. The next section illustrates conceptual framework and hypotheses concerning the direct effect of location drivers on performance as well as the moderating effect of governance model. The methodology section describes the sample, the operationalization of variables and the econometric models employed to test our hypotheses. The results of the analyses, their discussion and conclusions are then provided in the last three sections. 


\section{CONCEPTUAL FRAMEWORK AND HYPOTHESES}

\subsection{Location drivers}

Although some recent contributors address the issue of location choice and offshoring destination attributes from a theoretical (Graf and Mudambi, 2005) and an empirical perspective (Deloitte, 2004), it is still necessary to understand the importance of the location dimension (Jensen and Pedersen, 2011), and their impact on firm's competitive advantage and performance as firms are increasingly implementing strategies to exploit comparative advantages of locations (Mudambi, 2008).

Several authors (Bunyaratavej et al., 2008; Hatonen 2009; Roza et al., 2011) investigate location specific factors influencing the offshoring location choice. The decision to locate a specific offshore facility requires firms to trade off competing factors, seeking the best combination of cost and other productive inputs to maximize overall utility for that particular activity (Doh et al., 2009; Jensen and Pedersen, 2011).

The literature on location choices suggests taxonomies that cover the most important local features that attract foreign investors. According with Jensen and Pedersen (2010), relevant location attributes could be grouped under the four following headings.

- Cost of labor. Labor cost is probably the most important determinant, as offshoring is usually motivated by the possibility to benefit of lower wage standards of foreign countries (Stringfellow et al., 2008). However, the literature shows contradicting evidence regarding - for in instance - cost performance associated with offshoring projects, as much variability is observed, often preventing to achieve the expected outcomes (e.g., Bhalla et al., 2008). In parallel, some studies also show that the ramifications of outsourcing go well beyond immediate cost reduction (Ellram et al., 2007; Contractor et al., 2010; Mudambi and Venzin, 2010). 
- Resource availability. Human and technological resources heavily motivate the choice of the country where activities are offshored (Jensen and Pedersen, 2011; Luzzini and Ronchi, 2010). For example, the literature emphasizes the abundance and quality of human capital (Doh, 2005), the access to talents (Roza et al., 2011; Couto et al., 2007; Lewin et al., 2009); the presence of service providers (Bunyaratavej et al., 2008).

- Cultural proximity (or low Interaction distance) refers to geographical connections (Stringfellow et al., 2008), language (Karmarkar, 2004) and cultural factors (Youngdahl et al., 2010).

- Business environment and local networks. A firm might decide to offshore some activities in a country offering opportunities such as the access to local markets (Corbett, 2004; Kedia et al., 2009; Jensen, 2009; Roza et al., 2011), the co-location with existing manufacturing plants (Lewin et al., 2009; Hatonen, 2009; Temouri et al., 2010), or government and regulation incentives (Bunyaratavej et al., 2008; Hatonen, 2009).

However, these factors have been rarely related to performance (Kotabe and Omura, 1989; Kedia and Mukherjee, 2009; Roza et al., 2011).

\subsection{Offshoring performance}

In terms of offshoring effects, there is little consensus as to what the impacts of offshoring are at different levels, i.e. national, industry sector, firm (Doh, 2005). Farrell (2005) mainly stresses the economic benefits for companies of offshoring to low-cost destinations, but also notes that cost savings are only the beginning. While price reductions still are a major reason for offshoring, the breath of implications for operational as well as strategic management and performance is much broader (Ellram et al., 2008). 
Some works on the impact of offshoring exist (including services offshoring), notably on the job impact in developed countries (Amiti and Wei, 2005; Farrell et al., 2006; Farrell, 2005; Gereffi, 2006; Jensen et al., 2006; Sturgeon, 2006; Ernst, 2002; Patibandla and Petersen, 2002), on firm's financial performance (Kotabe and Murray, 2004), as well as on the dynamics of the offshoring process (Lewin and Peeters, 2006; Maskell et al., 2007). Scholars also consider different measures of the offshoring project's success, including the organization's satisfaction with the results and the degree of fulfillment with expectations (Wullenweber et al., 2008; Balaji and Ahuja, 2005; Dahlberg and Nyrhinen, 2006), the computed cost/benefit (Wang, 2002), the psychological belief of fulfilled obligations (Koh et al., 2004), and the strategic fit view (Lee et al., 2004). Nevertheless, the issue of impacts remains a major question in offshoring research and it not easily uncovered, due to its many facets.

In order to cope with such complexity, we note that, on the one hand, the academic literature often describes offshoring as an efficiency-seeking international strategy, associated to the possibility to reduce wages and other operational costs and/or to access specialized and productive resources (Dunning and Lundan, 2008; Jensen, 2009; Jensen and Pedersen, 2011). On the other hand, in recent years a resource-seeking strategy has been emphasized. As a matter of fact, offshoring and global sourcing strategies have frequent linkages with marketing and foreign market access strategies (Kotabe, 1992, 2001; Kotabe et al., 2009; Kotabe and Murray, 2004), as well as consumer sentiments (Thelen et al., 2011). While efficiency-seeking and resource-seeking motives in many cases play the dominant role, offshoring strategies include many additional nuances with firm-specific considerations regarding the interfaces between geographical location, access to knowledge, and access to foreign markets.

As a consequence, offshoring may lead to different outcomes. We know that firms traditionally exploit service offshoring to decrease the cost and increase the productivity of certain activities, thus pursuing the enhancement of operational performance. Also, several 
authors agree that strategic benefits might stem from offshoring, such as market expansion, innovation, or growth. Such distinction is consistent with the classical operations management literature that clearly distinguish between operational and market performance (e.g. Hayes and Weelwrigth, 1984; Frohlich and Westbrook, 2001; or Swink et al., 2007).

We can therefore identify two types of offshoring performance that are worth considering:

- Operational performance, which represents performance dimensions related to the execution of the task offshored. We can list them as cost, time, quality, and flexibility. As anticipated, the offshoring literature often tends to collapse cost and time into one performance dimension referred to efficiency and/or productivity.

- Strategic performance, which represents performance dimensions that are not necessarily related to the task offshored, but rather identify the strategic advantages a firm might achieve as a consequence of offshoring. In particular, the literature discussed so far shows several possible sources of competitive advantage deriving from offshoring, such as the chance to enter new markets (therefore increasing sales) that is often accompanied by the new products/services development.

\subsection{Linking location drivers to offshoring performance}

It is quite common in the literature to relate outsourcing and offshoring to the firm approach in managing activities. For instance, offshoring of advanced tasks is associated to greater maturity and strategic objectives, while efficiency-seeking strategies for simple tasks aim at improving operational performance (Jensen, 2009; Jensen and Pedersen, 2012). As a matter of fact, efficiency-seeking motive is associated to the possibility to save wages and other operational costs and/or to access specialized resources (see Dunning and Lundan, 2008; Caniato et al., 2010; Ronchi et al., 2010). At the same time, authors suggest that firms offshore advanced tasks not in order to save costs but for the purpose of making broader and deeper use of their 
global knowledge network. Here, offshoring is a strategy for tapping into sources of new knowledge abroad which have a potential for contributing to the international competitiveness of the firm (see also Roy et al., 2004).

Moreover, some evidence supports the idea that firms do not offshore because they seek input factors that differ from those they have at home. Rather, they look for similarities in inputs. Therefore, a country is more likely to be a destination for service offshoring when conditions are similar to the home country (Bunyaratavej et al., 2007; Doh et al., 2009). Extant literature shows that this is especially true for services.

Hence, we expect firms seeking to improve strategic performance are targeting locations not too diverse from the home country and with local infrastructures available. Instead, firms seeking to improve operational performance are expected to target locations where costs are low and specialized resources are available.

Accordingly, our first hypotheses are articulated as follows:

H1. Offshoring location drivers reflecting the search for lower costs and for resources availability positively affect operational performance.

H1a. The search for low cost of labor positively affects operational performance.

H1b. The search for resources availability positively affects operational performance.

\section{H2. Offshoring location drivers reflecting the search for cultural proximity and business environment positively affect strategic performance.}

H2a. The search for cultural proximity (low interaction distance) positively affects strategic performance.

H2b. The search for business environment/local network positively affects strategic performance. 


\subsection{The role of the governance model}

Firms can either embark on offshoring internally, by setting up their own centers or subsidiaries (Bunyaratavej et al., 2008; Hutzschenreuter et al., 2011) in foreign countries while maintaining full ownership and control (captive offshoring) or externally by handing over business functions to independent foreign providers (offshore outsourcing) (Kedia and Mukherjee, 2009; Hahn and Bunyaratavej, 2010). A hybrid and rare governance form of offshoring is the joint-venture, when the firm is sharing risks and benefits with a foreign counterpart (Jahns et al. 2006). This solution becomes interesting for long-term and risky projects, as both parties ensure their contribution. However, only a small percentage of offshoring projects recurs to joint-ventures.

Even though the Governance model - i.e. the degree of ownership of the offshored function - does not affect performance directly (Leiblein et al., 2002), it might seriously compromise performance (Hutzschenreuter et al., 2011). Great risks as well as potential benefits are involved with this choice: managers should consider that not all targets can be achieved through a specific governance model (Hutzschenreuter et al., 2011). It is therefore interesting to ask what governance model is the most suitable in a given situation and/or local context (Tate et al., 2009).

According to the Transaction Cost Economics (TCE), market modes (i.e. the offshore outsourcing model) involve two or more firms, and therefore management and control of activities requires coordination and consensus among partner organizations. Instead, hierarchical modes are managed and controlled by a single entity that eliminates the need to gain cooperation and consensus from another firm (Ronchi, 2011; Brouthers and Brouthers, 2003). 
Relying on the TCE, we claim that the shift of a service function abroad could reduce transaction costs, thus improving the performance of the offshoring project and the business overall (Aron et al., 2008). TCE clearly acknowledges that outsourcing is likely driven by cost reduction strategies as it allow to reduce costs thanks to suppliers specialization, economy of scale, and economy of learning, as well as to transform fixed into variable costs, thus managing demand uncertainty. Therefore, the captive solution might introduce higher costs than the outsourcing case, also as a result of investments necessary to acquire or establish a foreign subsidiary. Consequently, we expect that the quest for low costs and talent will more greatly impact performance in case of offshore outsourcing. So, our third research hypothesis the following:

H3. Location drivers reflecting the search for lower costs and resources availability lead to higher (operational) performance when the chosen governance form is outsourcing.

Hypothesis 3a. The search for low cost of labor leads to higher (operational) performance when the chosen governance model is outsourcing.

Hypothesis $3 b$. The search for resources availability leads to higher (operational) performance when the chosen governance model is outsourcing.

In the same vein, we expect firms will benefit of captive offshoring when strategic decisions driven by cultural proximity and local network are at stake. As a matter of fact, offshoring can only partially be explained by a single theory of the firm like TCE (Vivek et al., 2009), as benefits stemming from offshoring go well beyond cost reduction. Other studies suggest that RBV integrate TCE by considering positive effects a firm can obtain by appropriating critical resources abroad through a captive form of offshoring. Hence, we expect that a captive offshoring model would allow to grasp all the opportunities that come along with 
offshoring and improve overall firms’ performance (e.g., growth in new markets, innovation, and differentiation) (Lewin et al., 2008; Hutzschenreuter et al., 2011).

The RBV of the firm explains how the access to resources could improve performance (Roza et al., 2011; Jahns et al., 2011; Tate et al., 2009). In order to fully exploit benefits that arise from these resources, offshoring firms need to own (or at least to control) their valuable and rare resources in order to avoid imitation and substitution, and to secure the rent deriving from competitive advantage (Rumelt, 1984; Wernerfelt, 1984). For this reason, the RBV attributes a higher potential to increase performance to internal resources that are directly controlled or owned by the firm (Barney, 1991; Amit and Schoemaker, 1993). In summary, our fourth hypothesis is as follows:

H4. Location reflecting the search for cultural proximity and business environment lead to higher (strategic) performance when the chosen governance form is captive.

Hypothesis 4a. The search for cultural proximity (low interaction distance) leads to higher (strategic) performance when the chosen governance model is captive.

Hypothesis 4b. The search for business environment/local network leads to higher (strategic) performance when the chosen governance model is captive. 


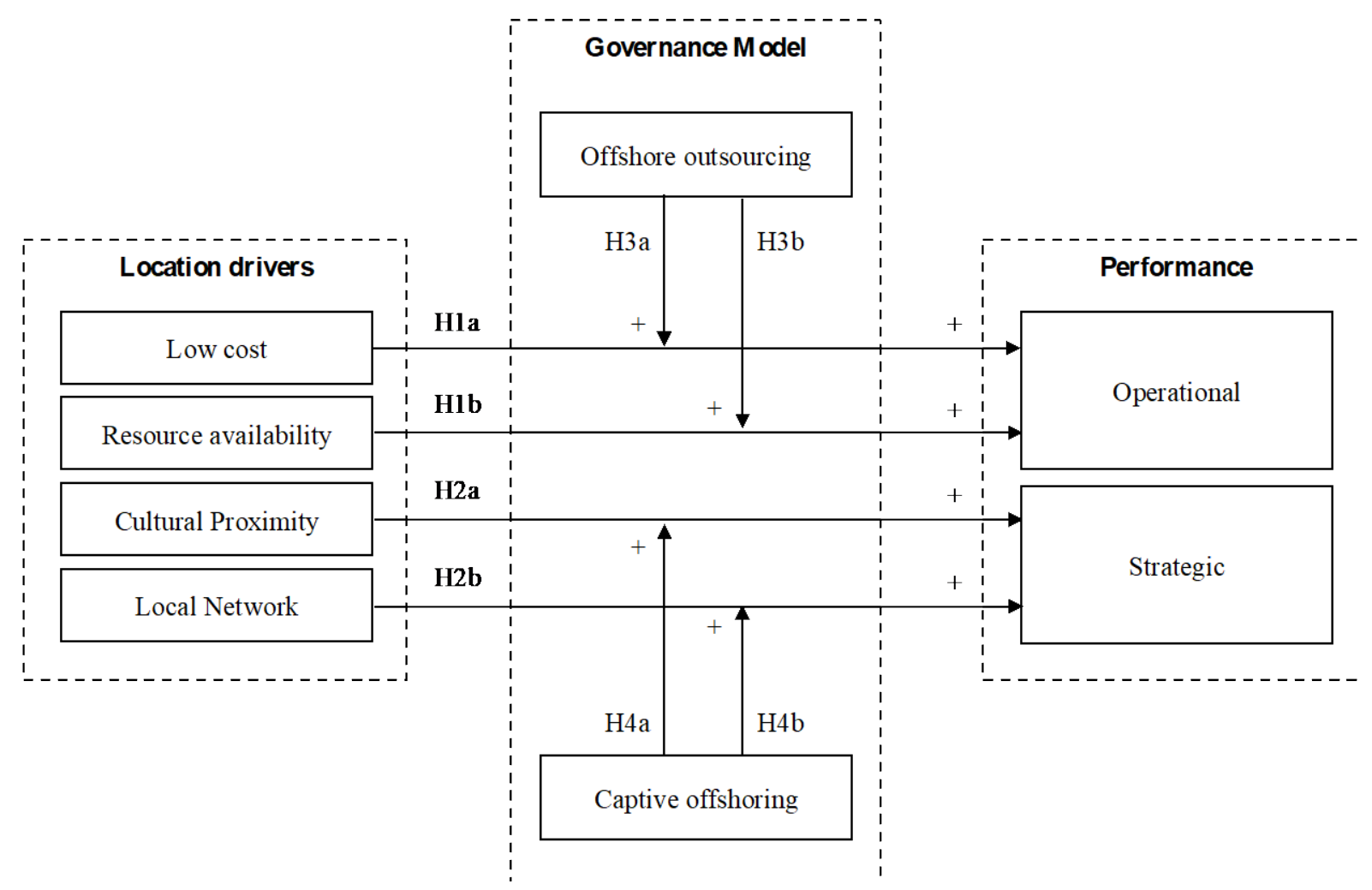

Figure 1. Research framework 


\section{METHODOLOGY}

\subsection{Sample}

In order to test our hypotheses, we used data collected within the 2009 edition of the Offshoring Research Network (ORN) survey (https://offshoring.fuqua.duke.edu, see also Lewin et al., 2011). ORN is an international research project, initiated in 2004, aimed at investigating the phenomenon of offshoring of technical and administrative services. The project is carried out by a network of academic partners from Australia, Belgium, Denmark, France, Germany, Italy, the Netherlands, Spain, United Kingdom, and USA. All partners contribute to data gathering in their home countries, administering a common online questionnaire and thus contributing to the development of a common database. The questionnaire investigates drivers, location characteristics, governance model and performance of offshored functions. The unit of analysis is the single function offshored by the firm; therefore, respondents could provide separate information on multiple functions, which are recorded as separate answers. The overall database of the 2009 edition of the ORN survey contains information on 866 offshored functions. However, only a subset of them was usable for the purpose of this study.

In fact, a reduction in the number of available observations has been performed to guarantee the absence of missing values in the variables that are relevant for our purposes, in particular location characteristics, governance model and offshoring performance, which brings the sample size down to 142 observations.

The sample is described in the following tables. It can be observed that the majority of firms are headquartered in the US (due to the genesis of the ORN project) and the offshoring destinations are mostly emerging countries. 


\begin{tabular}{lcc}
\hline \multicolumn{1}{c}{ Company Size } & Freq. & \% \\
\hline Small $(<500)$ & 21 & 14.8 \\
Medium $(>500 ;<20,000)$ & 66 & 46.5 \\
Large $(>20,000)$ & 55 & 38.7 \\
\hline Total & $\mathbf{1 4 2}$ & $\mathbf{1 0 0}$ \\
\hline
\end{tabular}

Table 1. Company Size (number of employees)

\begin{tabular}{lcc}
\hline Industry & Freq. & $\mathbf{\%}$ \\
\hline Aerospace & 2 & $1,4 \%$ \\
Arts, Entertainment and Recreation & 7 & $4,9 \%$ \\
Biotech and Pharmaceutical & 2 & $1,4 \%$ \\
Finance and Insurance & 63 & $44,4 \%$ \\
Health Care and Social Assistance & 4 & $2,8 \%$ \\
Management of Companies and Enterprises & 4 & $2,8 \%$ \\
Not-for-profit Organization/NGO & 2 & $1,4 \%$ \\
Other Manufacturing & 28 & $19,7 \%$ \\
Professional, Scientific, and Technical & 1 & $0,7 \%$ \\
Public Administration & 8 & $5,6 \%$ \\
Retail Trade & 2 & $1,4 \%$ \\
Software & 17 & $12,0 \%$ \\
Telecommunications & 2 & $1,4 \%$ \\
\hline Total & $\mathbf{1 4 2}$ & $\mathbf{1 0 0} \%$ \\
\hline
\end{tabular}

Table 2. Industry

\begin{tabular}{lrr}
\hline \multicolumn{1}{c}{ Home Country Areas } & Freq. & Percent \\
\hline Australia & $\mathbf{5}$ & $\mathbf{3 . 5}$ \\
Emerging Countries & $\mathbf{5}$ & $\mathbf{3 . 5}$ \\
China & 2 & 1.4 \\
India & 3 & 2.1 \\
Europe & $\mathbf{3 7}$ & $\mathbf{2 6 . 1}$ \\
$\quad 1$ & 0.7 \\
Austria & 1 & 1.4 \\
Denmark & 2 & 0.7 \\
Luxembourg & 1 & 1.4 \\
Norway & 2 & 6.3 \\
Spain & 9 & 9.2 \\
Switzerland & 13 & 6.3 \\
$\quad$ United Kingdom & 9 & $\mathbf{6 6 . 9}$ \\
United States & $\mathbf{9 5}$ & $\mathbf{1 0 0}$ \\
\hline Total & $\mathbf{1 4 2}$ & \\
\hline
\end{tabular}

Table 3. Home country of the offshoring projects 


\begin{tabular}{lcc}
\hline Function & Freq. & $\mathbf{~ \% ~}$ \\
\hline Call center and Customer contact & 22 & 15.5 \\
Finance and Accounting & 21 & 14.8 \\
Human Resources & 6 & 4.2 \\
Information Technology & 32 & 22.5 \\
Knowledge Services & 23 & 16.2 \\
Legal Services & 3 & 2.1 \\
Engineering Services & 10 & 7.0 \\
Software & 25 & 17.6 \\
\hline Total & $\mathbf{1 4 2}$ & $\mathbf{1 0 0}$ \\
\hline
\end{tabular}

Table 4. Company functions offshored

\begin{tabular}{lrr}
\hline Countries & Freq. & \multicolumn{1}{c}{ \% } \\
\hline Advanced Countries & $\mathbf{1 9}$ & $\mathbf{1 3 . 4}$ \\
United Kingdom & 2 & 1.4 \\
United States & 4 & 2.8 \\
Spain & 8 & 5.6 \\
Sweden & 1 & 0.7 \\
Finland & 1 & 0.7 \\
Canada & 3 & 2.1 \\
Emerging Countries & $\mathbf{1 2 3}$ & $\mathbf{8 6 . 6}$ \\
Brazil & 2 & 1.4 \\
China & 10 & 7.0 \\
Costa Rica & 3 & 2.1 \\
Czech Republic & 2 & 1.4 \\
Estonia & 1 & 0.7 \\
Hungary & 2 & 1.4 \\
India & 70 & 49.3 \\
Indonesia & 1 & 0.7 \\
Jamaica & 1 & 0.7 \\
Lithuania & 1 & 0.7 \\
Malaysia & 1 & 0.7 \\
Mauritius & 1 & 0.7 \\
Mexico & 1 & 0.7 \\
Philippines & 10 & 7.0 \\
Poland & 2 & 1.4 \\
Romania & 2 & 1.4 \\
Russian Federation & 1 & 0.7 \\
Singapore & 4 & 2.8 \\
Slovakia & 2 & 1.4 \\
South Africa & 3 & 2.1 \\
Turkey & 1 & 0.7 \\
Ukraine & 2 & 1.4 \\
\hline Total & $\mathbf{1 4 2}$ & $\mathbf{1 0 0 . 0 0}$ \\
\hline & &
\end{tabular}

Table 5. Host country of the offshoring projects 


\section{2. $\quad$ Measures}

The variables used to investigate our hypotheses are obtained from the following questions: Main variables

- Location drivers: Why was this particular location chosen? (Likert scale from 1strongly disagree to 5-strongly disagree, 10 items)

- Performance: To what extent do you agree that offshoring has measurably led to the following outcomes? (Likert scale from 1- strongly disagree to 5 - strongly disagree, 8 items)

- Governance Model: What is the service delivery model currently used for this offshoring implementation? (0 - Captive: fully owned offshore subsidiary; 1 Outsourcing: third-party service provider at the offshore location)

While Location drivers and Governance Model variables refer specifically to the single function offshored, Performance variables refer to the overall firm level, although considering the impact of offshoring on such performance. This shift in the level of analysis is due to the willingness to assess firm performance overall, not the single function per se. In order to increase validity and reduce the number of variables, both location drivers and performance variables have been aggregated on the base of an Exploratory Factor Analysis, based on Principal Components and adopting a Varimax rotation (see Table 6 and 7). Validity is confirmed by the high factor loadings on just one construct at a time, as well as by the high total variance explained. Reliability is confirmed by the values of Cronbach's Alpha, all above the minimum threshold of 0.6. The new variables have been computed as linear combinations of the original variables with factor scores and standardized. Two variables have been obtained for performance, i.e. Strategic and Operational Performance, and four variables for location drivers, i.e. Low Cost, Resource Availability, Cultural Proximity and Local Network. 


\begin{tabular}{lcccc}
\hline First-order construct & Indicator code & Indicators* & Loading & Alpha \\
\hline \multirow{2}{*}{ Low cost } & loc_labcost & Low costs & .874 \\
& loc_othcost & Other costs (besides labor costs) & .867 & .715 \\
\hline \multirow{2}{*}{ Resource availability } & loc_expert & High level of expertise & .786 & .738 \\
& loc_provloc & Location of the best service provider & .834 & .832 \\
\hline \multirow{2}{*}{ Cultural proximity } & loc_talent & Talent pool available & .678 \\
& loc_lang & Matches language requirements & .868 \\
\hline \multirow{2}{*}{ Local network } & loc_proxcult & Cultural proximity & .842 & .835 \\
& loc_customer & Access to local market & .828 \\
& loc_colman & Collocating with existing manufacturing plant offshore & .834 \\
\hline
\end{tabular}

All eigenvalues $>1$, total variance explained 73\%

* The question was “Why was this particular location chosen?” [1-'Strongly disagree' 5-'Strongly agree']

Table 6. Exploratory Factor Analysis on location drivers

\begin{tabular}{llllc}
\hline First-order construct & Indicator code & Indicators* & Loading & Alpha \\
& out_newmark & Better access to new markets & .866 \\
& out_prodinno & Major product innovation(s) & .834 & .846 \\
Strategic performance & out_firmgrw & Firm growth & .774 \\
& out_compete & Increase in firm's overall competitiveness & .755 \\
\hline \multirow{2}{*}{ Operational performance } & out_servqual & Improved service quality & .837 \\
& out_prodeff & Increased productivity/efficiency & .693 \\
& out_orgflex & Improved organizational flexibility & .713 & .750 \\
& out_aqp & Better access to qualified personnel & .657 \\
\hline
\end{tabular}

All eigenvalues $>1$, total variance explained $64 \%$

* The question was “To what extent do you agree that offshoring has measurably led to the following outcomes?” [1-'Strongly disagree' 5-'Strongly agree']

Table 7. Exploratory Factor Analysis on offshoring performance 


\begin{tabular}{lrrrrrrrr}
\hline & \multicolumn{1}{l}{ 1) } & 2) & 3) & 4) & 5) & 6) & 7) & 8) \\
\hline 1) Strategic Performance & 1 & & & & & & \\
2) Operational Performance & -0.170 & 1 & & & & & \\
3) Local Network & 0.516 & -0.268 & 1 & & & & \\
4) Resource Availability & 0.111 & 0.540 & -0.104 & 1 & & & \\
5) Cultural Proximity & 0.153 & -0.087 & -0.016 & -0.008 & 1 & & \\
6) Low Cost & 0.255 & 0.047 & 0.025 & -0.038 & 0.020 & 1 & \\
7) Governance Model & -0.137 & 0.001 & -0.261 & 0.271 & 0.148 & -0.014 & 1 \\
8) Size & -0.293 & 0.277 & -0.222 & 0.251 & -0.083 & -0.038 & 0.153 & 1 \\
\hline
\end{tabular}

Table 8. Correlation matrix of dependent and independent variables

\section{Control variables}

- Company size: the logarithm of the total employees of the offshoring firm.

- Home Country Area of the offshoring firm. A set of dummy variables that distinguish among four different areas: Europe, USA, Australia and Emerging Countries.

- Offshored Function. A dummy variable has been introduced for each single function included in the offshoring project, namely call center and customer contact, information technology, software development, finance/accounting, human resources, analytical/knowledge services, legal services, and engineering services.

- Host Country of the offshoring project: dummy variable, equal to 1 when the destination country is an Emerging country, and 0 otherwise.

In order to further check the quality of our data, we performed a set of tests. As far as Common Method Bias is concerned, it is worth observing that the variables used in our analysis were located in different sections of the questionnaire and anonymity was guaranteed to respondents, as suggested by most authors (Conway and Lance, 2010; Podsakoff et al., 2003). Subsequently we performed the Harman's single factor test (Podsakoff et al., 2003), which 
showed that a single factor accounts for a very limited portion of total variance, thus suggesting that CMB is not a major concern with our dataset.

\section{3. $\quad$ Models}

Since firms select the governance model based on their expectation of future performance, an endogeneity problem may arise when using the governance model as explicative variable of firms’ performance (Shaver, 1998; Hamilton and Nickerson, 2003). Statistical analyses that do not take into account this self-selection process can suffer from biased estimations, resulting from underlying omitted and unobserved factors affecting both strategy choice and performance (Hamilton and Nickerson, 2003). As a consequence, following Shaver (1998) and Leiblein et al. (2002), we adopted a two-stage approach à la Heckman $(1976,1979)$ in order to control for the potential endogeneity problem arising from the self-selection bias. Specifically, in the first stage we estimated a probit model (Model 1), where the dependent variable is the governance model and the independent variables are the company Size, the Home Country Area of the offshoring firm, the Host Country of the offshoring project, the Offshored Function, and the Location Drivers. This allowed us to calculate the inverse Mills ratio $\lambda$ (as in Leiblein et al., 2002), to be used as a control variable in the second stage, thus providing consistent and unbiased estimates (e.g. Greene 1997).

In the second stage we estimated a set of models to test our hypotheses. Namely, we considered performances (both strategic and operational) as dependent variables, and location drivers, governance model and controls as independent ones.

In Model 2 we included the location drivers and the governance model without the inverse Mills ratio; in Model 3 we included also this control, in order to test hypotheses H1 and H2, while also checking whether the governance model direct effect on performance is actually due to the selection model. 
In order to test $\mathrm{H} 3$ and $\mathrm{H} 4$ instead we split the sample on the base of the governance model and estimated Model 4 and Model 5, which are the same as Model 3 but with the two subsamples $^{1}$.

Therefore in stage 1 the model is the following:

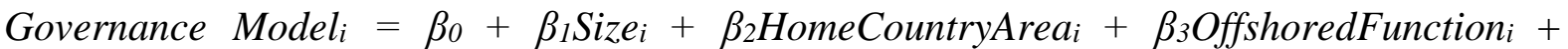
$\beta_{4}$ HostCountryi $_{i}+\varepsilon_{I} \quad$ (Model 1)

In stage 2 the models considered are the following:

Performance $_{i}=\beta_{0}+\beta_{1}$ Low $_{\text {Cost }}+\beta_{2}$ ResourceAvailability $_{i}+\beta_{3}$ CulturalProximity $_{i}+$ $\beta_{4}$ LocalNetwork $_{i}+\beta_{5}$ GovernanceModel $_{i}+\beta_{6}$ Controls $_{i}+\varepsilon_{I}$ (Model 2)

and

Performance $_{i}=\beta_{0}+\beta_{1}$ LowCost $_{i}+\beta_{2}$ ResourceAvailability $_{i}+\beta_{3}$ CulturalProximity $_{i}+$ $\beta_{4}$ LocalNetwork $_{i}+\beta_{5}$ GovernanceModel $_{i}+\beta_{6}$ Controls $_{i}+\beta_{7}$ InverseMillsRatio $_{i}+\varepsilon \mathrm{I}$ (Model 3, 4, 5)

where $i$ is the offshoring project; Governance Modeli is the form of the offshoring project, i.e. captive offshoring or offshored outsourcing; Size $e_{i}$ is the offshoring company size,

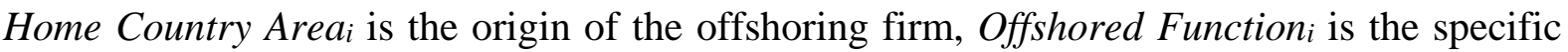
company function included in the offshoring project, Host Country is the destination of the offshoring project. Performance $e_{i}$ is the performance of the firm associated to each offshoring project, Low Cost, Resource Availabilityi, Cultural Proximity $y_{i}$ and Local Network are the

${ }^{1}$ To test the significance of the differences between models 4 and 5 , we ran a set of additional models, introducing the interaction effects between governance model and each location driver one at a time, due to the small sample size. 
location drivers associated to each offshoring project; Controls $s_{i}$ are the control variables, Inverse Mills Ratio is the value obtained from the first stage and $\varepsilon_{i}$ is the error term.

\section{RESULTS}

Results of the first-stage analysis, i.e. Model 1, are reported in Table 9. We can observe that the selection of the governance model, i.e. the choice between captive offshoring and offshored outsourcing, is indeed dependent upon company and transaction specific factors such as company size, home country and the specific offshored function. Only the selection of emerging vs. advanced countries as destination for the offshoring project does not appear to have a significant impact on this decision. This preliminary step, as previously described, is not intended as a result per se, rather it is functional at the investigation of our research hypotheses in the subsequent stage.

\begin{tabular}{|c|c|}
\hline Independent variables & Coefficient (z) \\
\hline Size & $\begin{array}{l}0.124 * \\
(2.07)\end{array}$ \\
\hline \multicolumn{2}{|l|}{ Home Country Area } \\
\hline Dummy Home Country Area Australia & $\begin{array}{l}-0.758 \\
(-1.41)\end{array}$ \\
\hline Dummy Home Country Area Emerging Countries & $\begin{array}{l}-0.607 \\
(-0.92)\end{array}$ \\
\hline Dummy Home Country Area Europe & $\begin{array}{l}0.793^{*} \\
(2.49)\end{array}$ \\
\hline \multicolumn{2}{|l|}{ Offshored Function } \\
\hline Dummy Function Human Resources & $\begin{array}{c}-1.324 * \\
(-2.26)\end{array}$ \\
\hline Dummy Function Information Technology & $\begin{array}{l}-0.180 \\
(-0.46)\end{array}$ \\
\hline Dummy Function Knowledge Services & $\begin{array}{l}-0.292 \\
(-0.69)\end{array}$ \\
\hline Dummy Function Legal Services & $\begin{array}{c}0.667 \\
(-0.81)\end{array}$ \\
\hline Dummy Function Call center and Customer contact & $\begin{array}{l}0.553 \\
(1.09)\end{array}$ \\
\hline Dummy Function Engineering Services & $\begin{array}{c}-1.090 \\
(-2.01)^{*}\end{array}$ \\
\hline Dummy Function Finance and Accounting & $\begin{array}{c}-1.216 \\
(-2.96)^{* *}\end{array}$ \\
\hline \multicolumn{2}{|l|}{ Host country } \\
\hline Dummy Host Country Emerging Countries & $\begin{array}{l}0.094 \\
(0.25)\end{array}$ \\
\hline Constant & $\begin{array}{l}-1.634^{*} \\
(-2.33)\end{array}$ \\
\hline Number of observations & 142 \\
\hline Wald Chi-Square & 39.67 \\
\hline Prob > Chi-Square & 0.0001 \\
\hline Pseudo R-Square & 0.1967 \\
\hline Log-pseudolikelihood & -73.495763 \\
\hline
\end{tabular}


Dependent variable: $0=$ captive offshoring; $1=$ offshore outsourcing

Dummy United States and Dummy Function Software omitted because of collinearity

Table 9. First-stage: Governance Model selection (Model 1)

Table 10 and 11 presents the results of the second-stage analyses, i.e. the regression Models 2-5 that investigate our research hypotheses. In particular Models 2 and 3 (Table 10) address $\mathrm{H} 1$ and H2, considering strategic and operational performance as dependent variables and location drivers as independent ones, while controlling for governance model and company size. In Model 2, governance model has a significant, negative effect on operational performance only. However, in Model 3, when including also the inverse Mills ratio obtained from the previous stage (Model 1), the governance model shows no more significant impact on any performance, while the inverse Mills ratio has a significant effect on operational performance. This result confirms that governance selection is indeed depending upon underlying factors and therefore control for self-selection is needed, as suggested by Leiblein et al. (2002). Therefore, in the following, we consider only Model 3 to test our hypotheses. Results shows that low cost and resource availability have a positive and significant effect (with $\mathrm{p}<0.05$ and $\mathrm{p}<0.001$, respectively) on operational performance, thus confirming hypotheses 1a and 1b. However, low cost and resource availability display a positive and significant effect (both with $\mathrm{p}<0.01$ ) also for the strategic performance. At the same time, local network shows a positive and significant effect (with $\mathrm{p}<0.001$ ) on strategic performance, thus confirming hypothesis 2b. Conversely, we do not find support for hypothesis 2a. Local network also displays a negative and significant impact on operational performance $(\mathrm{p}<0.001)$. 


\begin{tabular}{|c|c|c|c|c|}
\hline \multirow[b]{2}{*}{ Independent Variables } & \multicolumn{2}{|c|}{ Model 2} & \multicolumn{2}{|c|}{ Model 3} \\
\hline & $\begin{array}{c}\text { Strategic } \\
\text { Performance }\end{array}$ & $\begin{array}{l}\text { Operational } \\
\text { Performance }\end{array}$ & $\begin{array}{c}\text { Strategic } \\
\text { Performance }\end{array}$ & $\begin{array}{l}\text { Operational } \\
\text { Performance }\end{array}$ \\
\hline \multicolumn{5}{|c|}{ Location Drivers and Governance model } \\
\hline Low Cost & $\begin{array}{c}0.244 * * * \\
(3.65)\end{array}$ & $\begin{array}{l}0.086 \\
(1.12)\end{array}$ & $\begin{array}{c}0.249 * * \\
(3.47)\end{array}$ & $\begin{array}{l}0.141^{*} \\
(2.01)\end{array}$ \\
\hline Resource Availability & $\begin{array}{c}0.202^{* *} \\
(3.12)\end{array}$ & $\begin{array}{c}0.565 * * * \\
(7.79)\end{array}$ & $\begin{array}{c}0.199 * * \\
(3.04)\end{array}$ & $\begin{array}{c}0.538 * * * \\
(8.29)\end{array}$ \\
\hline Cultural Proximity & $\begin{array}{l}0.122 \\
(1.74)\end{array}$ & $\begin{array}{l}-0.123 \\
(-1.93)\end{array}$ & $\begin{array}{l}0.123 \\
(1.78)\end{array}$ & $\begin{array}{l}-0.110 \\
(-1.69)\end{array}$ \\
\hline Local Network & $\begin{array}{c}0.461 * * * \\
(7.41)\end{array}$ & $\begin{array}{c}-0.262 * * \\
(-3.56)\end{array}$ & $\begin{array}{c}0.456 * * * \\
(6.80)\end{array}$ & $\begin{array}{c}-0.327 * * * \\
(-4.16)\end{array}$ \\
\hline Governance Model & $\begin{array}{c}-0.85 \\
(-0.69)\end{array}$ & $\begin{array}{c}-0.529 * * \\
(-3.21)\end{array}$ & $\begin{array}{l}-0.065 \\
(-0.49)\end{array}$ & $\begin{array}{l}-0.278 \\
(-1.65)\end{array}$ \\
\hline \multicolumn{5}{|l|}{ Control Variables } \\
\hline Inverse Mills ratio & & & $\begin{array}{l}0.054 \\
(0.29)\end{array}$ & $\begin{array}{c}0.690 * * * \\
(3.73)\end{array}$ \\
\hline Size & $\begin{array}{l}-0.086^{* *} \\
(-3.25)\end{array}$ & $\begin{array}{l}0.047 \\
(1.54)\end{array}$ & $\begin{array}{c}-0.082^{* *} \\
(-2.72)\end{array}$ & $\begin{array}{r}0.088^{* *} \\
(3.08)\end{array}$ \\
\hline Constant & $\begin{array}{c}0.717^{* *} \\
(3.05)\end{array}$ & $\begin{array}{l}-0.060 \\
(-0.20)\end{array}$ & $\begin{array}{l}0.642 \\
(1.74)\end{array}$ & $\begin{array}{c}-1.020 * * \\
(-2.96)\end{array}$ \\
\hline Number of observations & 142 & 142 & 142 & 142 \\
\hline R-Square & 0.437 & 0.398 & 0.437 & 0.449 \\
\hline F-Test & $21.61 * * *$ & $19.61 * * *$ & $18.43 * * *$ & $16.17 * * *$ \\
\hline
\end{tabular}

Table 10. Second-stage: regression models (full sample)

Table 11 presents the last two models (Model 4 and Model 5), testing H3 and H4, i.e. the role of the governance model on the relationship between location drivers and performance. In order to do so we split the sample according to the governance model, thus estimating unconstrained coefficients to check whether the different governance model leads to different relationships. We find that the coefficient of the positive effect of resource availability on operational performance is higher in case of outsourcing than in case of captive offshoring, thus providing partial support to hypothesis 3b, although the difference between the two values is not significant. We do not find support, however, for hypothesis 3a, given that low cost has no impact on operational performance.

Results also show that local network positively affects the strategic performance with a higher coefficient in case of captive than in case of outsourcing offshoring (although the difference is not statistically significant), thus providing partial support for hypothesis 4b. 
Conversely, hypothesis $4 \mathrm{a}$ is not supported by our results, since cultural proximity has a positive impact on strategic performance only in the case of outsourcing (the difference is significant at $\mathrm{p}<0.5$ ).

In addition, we found other differences between the two samples: low cost positively affects strategic performance only in case of captive offshoring (this difference is significant at $\mathrm{p}<0.05)$. Strategic performance is positively affected by resource availability only in case of offshore outsourcing (the difference is not significant); local network has a negative impact on operational performance only in case of offshore outsourcing (this difference is significant at $\mathrm{p}<0.1)$

\begin{tabular}{|c|c|c|c|c|}
\hline \multirow[b]{2}{*}{ Independent Variables } & \multicolumn{2}{|c|}{ Model 4 (Captive offshoring) } & \multicolumn{2}{|c|}{ Model 5 (Offshore outsourcing) } \\
\hline & $\begin{array}{c}\text { Strategic } \\
\text { Performance }\end{array}$ & $\begin{array}{l}\text { Operational } \\
\text { Performance }\end{array}$ & $\begin{array}{c}\text { Strategic } \\
\text { Performance }\end{array}$ & $\begin{array}{l}\text { Operational } \\
\text { Performance }\end{array}$ \\
\hline \multicolumn{5}{|l|}{ Location Drivers and Governance model } \\
\hline Low Cost & $\begin{array}{c}0.328^{* *} \\
(3.58)\end{array}$ & $\begin{array}{l}0.098 \\
(0.70)\end{array}$ & $\begin{array}{l}0.192 \\
(1.79)\end{array}$ & $\begin{array}{l}0.136 \\
(1.57)\end{array}$ \\
\hline Resource Availability & $\begin{array}{l}0.109 \\
(1.36)\end{array}$ & $\begin{array}{c}0.431 * * \\
(3.63)\end{array}$ & $\begin{array}{l}0.251^{*} \\
(2.45)\end{array}$ & $\begin{array}{l}0.554 * * * \\
(5.76)\end{array}$ \\
\hline Cultural Proximity & $\begin{array}{l}-0.017 \\
(-0.14)\end{array}$ & $\begin{array}{l}-0.176 \\
(-1.05)\end{array}$ & $\begin{array}{l}0.190^{*} \\
(2.44)\end{array}$ & $\begin{array}{l}-0.087 \\
(-1.42)\end{array}$ \\
\hline Local Network & $\begin{array}{c}0.521^{* *} \\
(3.46)\end{array}$ & $\begin{array}{l}-0.197 \\
(-1.03)\end{array}$ & $\begin{array}{c}0.423^{* * *} \\
(6.04)\end{array}$ & $\begin{array}{c}-0.380 * * * \\
(-4.75)\end{array}$ \\
\hline \multicolumn{5}{|l|}{ Control Variables } \\
\hline Inverse Mills ratio & $\begin{array}{l}0.017 \\
(0.09)\end{array}$ & $\begin{array}{c}0.881^{* *} \\
(3.16)\end{array}$ & $\begin{array}{l}0.330 \\
(0.86)\end{array}$ & $\begin{array}{l}0.467^{*} \\
(2.16)\end{array}$ \\
\hline Size & $\begin{array}{l}-0.059 \\
(-1.08)\end{array}$ & $\begin{array}{c}0.134 \\
(1.74)\end{array}$ & $\begin{array}{c}-0.106^{* *} \\
(-2.77)\end{array}$ & $\begin{array}{r}0.080^{* *} \\
(2.90)\end{array}$ \\
\hline Constant & $\begin{array}{l}0.443 \\
(0.86)\end{array}$ & $\begin{array}{l}-1.623 \\
(-2.02)\end{array}$ & $\begin{array}{l}0.667 \\
(1.50)\end{array}$ & $\begin{array}{c}-1.149 * * * \\
(-4.02)\end{array}$ \\
\hline Number of observations & 49 & 49 & 93 & 93 \\
\hline R-Square & 0.616 & 0.335 & 0.341 & 0.558 \\
\hline F-Test & $14.40 * * *$ & $4.51^{* *}$ & $12.41 * * *$ & $20.57 * * *$ \\
\hline
\end{tabular}

${ }^{*} \mathrm{p}<0.05,{ }^{* *} \mathrm{p}<0.01,{ }^{* * *} \mathrm{p}<0.001$

Table 11. Second-stage: regression models (split sample) 


\section{DISCUSSION}

Our first two hypotheses focus on service offshoring and its impact on performance. In particular they analyse the impact of four major location drivers and characteristics (low cost, resource availability, cultural proximity, and local network) on operational and strategic performance.

Looking at the operational performance, hypotheses 1a and 1b are not rejected; both low cost and resource availability have a positive effect on operational performance. As a matter of fact, as discussed in the research framework section, low cost of labor has a direct impact on process efficiency and high level of expertise and competence helps the company in improving its performance in terms of service quality, flexibility and access to qualified personnel.

Results also highlight a negative and significant relation between local network and operational performance. This might be explained in a strategic and managerial perspective. The company would afford lower operational performance in the short run in order to grow and develop new markets in the long run (as this latter relationship between local network and strategic performance is positive - see below). In other words, in some cases in which the company has already some local interests and is interested in reaching a strategic goal of market development, it might be necessary to accept lower quality, service level or productivity for a specific offshored function.

As far as strategic performance is concerned, hypothesis $2 \mathrm{~b}$ is not rejected; local network has a positive impact on strategic performance. In other words, already existing operations and local customers support better access to new markets, major product innovations, firm growth, and increase in its overall competitiveness. This is coherent with what previously discussed in the paper: an existing local presence or an established network in the offshore country facilitate firm growth in the market. On the contrary, hypothesis $2 \mathrm{a}$ is rejected; cultural proximity is not significantly related to strategic performance. That means 
language and cultural factors do not necessarily affect the opportunity for new markets, product innovations and firm growth. In a strategic and managerial perspective, companies should not look mostly at similar countries to offshore their services, but also very distant regions (in terms of culture) could create good opportunities. Therefore, cultural distance should not be considered as a barrier to service offshoring when market growth and access to new customers is the desired outcome.

Results also show a positive and significant relationship between both low cost and resource availability and strategic performance. Not only low costs and competence availability improve operational performance, but they also foster market opportunities by creating competitive advantage.

Once analysed the relations between location drivers and performance, the research study investigates the role of the governance model (captive offshoring or offshore outsourcing) in influencing those relations.

Results show how the governance model influences the operational performance. In particular hypothesis $3 \mathrm{~b}$ is not rejected as the impact of resource availability on operational performance is higher in case of offshore outsourcing rather than in case of captive offshoring. When competences and resources are already available in the country, outsourcing would lead to higher operational performance. The degree of ownership might compromise performance as a captive solution might introduce higher and not necessary costs in terms of investments to acquire or to establish a foreign subsidiary. This is not true however for the low cost location driver, thus leading us to reject hypothesis 3a. The positive effect of low costs on operational performance becomes not significant when the sample is split, in case of both captive offshoring and offshore outsourcing model. However, sample size probably plays a role in this case (as we have 49 captive vs. 93 outsourcing initiatives). 
This further analysis could also add something to the previous discussion on the negative relation observed before between local network and operational performance. Results show that these local interests have a negative impact on operational performance only in case of offshore outsourcing. A possible explanation might be the following: in case of existing local networks the firm might be willing to offshore a specific function (aiming at strategic performance) even if the operational performance would be hampered; this low performance cannot be avoided if the function is outsourced to a local party, while a captive governance model would increase the control over the offshored function thus limiting associated risks and low productivity.

Finally, some considerations about the governance model emerge also in relation with the strategic performance. Hypothesis $4 \mathrm{~b}$ is not rejected, thus supporting the assumption that local networks have a greater impact on strategic performance in case of captive offshoring rather than in case of offshore outsourcing. In other words, in case the company has already some local interests (for example in terms of clients or existing plants) it might create more opportunities in terms of growth, innovation and new clients by further increasing its presence in the country through a captive offshored function. Therefore, the ability to create a sustainable competitive advantage in those markets is increased by directly controlling or owning offshored activities. On the contrary, hypothesis 4a is rejected; the offshore outsourcing governance model influences positively the relation between cultural proximity and strategic performance. We can interpret this result by arguing that outsourcing may require higher cultural proximity to provide strategic benefits, while this is less of an issue in case of captive offshoring.

These results show something more also regarding the relation between both low cost and resource availability, and strategic performance. The previous analysis has already shown a positive effect of these two location drivers on competitive advantage and strategic 
performance. On one side, captive offshoring increases the opportunity to leverage low costs in order to develop the customer market in the long run. Coherently with the literature, in order to fully exploit benefits deriving by local factors (i.e. low labor cost), offshoring firms need to own or to directly control their activities in order to avoid imitation and to secure the rent deriving from competitive advantage. On the other side, resource availability has a positive impact on strategic performance only in case of offshore outsourcing to a local party; in case the firm has decided to directly control the offshored function, the presence of local competences and skills do not influence the strategic performance. As a matter of fact, in this latter case the company might bring or create its own competences without leveraging existing ones in the offshore country.

\section{CONCLUSIONS}

This study investigates the antecedents of performance obtained by a company offshoring business services. In particular, the drivers and characteristics of the offshoring location (i.e., cost of labor, resource availability, cultural proximity, local network) and the governance model adopted (i.e., captive offshoring and offshore outsourcing) are considered.

The paper provides some new insights for both researchers and practitioners.

From a theoretical perspective, this study contributes to the previous literature on offshoring by studying the performance side of offshoring, rather than focusing on the antecedents of such a phenomenon, as other studies normally do. In fact, the impact on performance is a major issue in offshoring research (Kotabe and Omura, 1989; Doh, 2005; Kedia and Mukherjee, 2009; Roza et al., 2011). This research study also assesses the role of the governance model in influencing the relationships between location drivers and performance. Through a comprehensive literature review and a successive empirical analysis, 
our results support the idea that different location drivers and governance model do affect offshoring performance, with different impacts on strategic and operational performance.

In terms of managerial implications, the paper shows that low cost factors and resource availability positively impact operational performance and the existing local networks positively impacts strategic performance. On the contrary, cultural proximity has a limited role in determining strategic performance, therefore managers should not consider cultural barriers as a deterrent for service offshoring at all. Results also suggest that firms having an established local network and interest in developing new markets in the host country generally must face and accept low operational performance for a specific offshored function. Moreover, we find that outsourcing model strengthens the relationship between efficiency-seeking strategies and operational performance, while captive model positively moderates the relationship between resource-seeking strategies and strategic performance. Additionally, captive offshoring seems to reduce operational benefits deriving from resource availability in the short run due to the required investments; however, it would increase the opportunities for market development in the long run, especially in case the firm has already some local interests and operations in the country.

In conclusion, we are aware that this study has some limitations, which open up opportunities for further investigations and future research. In particular, the size of our sample does not allow to account for differences in offshoring drivers depending on the type of the service offshored, while characteristics of the function performed are likely to be relevant to determine the most suitable location (Doh et al., 2009). Moreover, it would be interesting to introduce the host country as a moderating effect on performance that firms aim to achieve by using offshoring, rather than a control variable. 
It would be worthwhile extending the analysis including the dynamics of the offshoring processes. In fact, among the aspects to be considered in order to understand performance result, the firm past experience within a specific location and/or with a specific form of governance is likely to play a role. Offshoring performance is certainly not only the result of wise choices, but it is also deriving from managerial experience within a global context.

A further area of improvement would be a comparison between service offshoring models and manufacturing offshoring models, especially in a moment in which some companies are back-sourcing or near-shoring some of their manufacturing activities due to the unexpected rise of costs and risks in the offshore locations. Related to that, a final limitation at the time of revision and publication is that the data gathering process occurred in 2009; in the following years some scenarios within the offshoring domain might have changed, especially related to manufacturing offshoring (e.g. back-sourcing, near-shoring, global financial crisis evolution), and these scenarios might impact also service offshoring activities.

Notwithstanding the limitations identified above, we believe results obtained and the insights discussed are valid. The limitations noted provide potential research opportunities for the future. 


\section{REFERENCES}

Abramovsky L, Griffith R. 2006. Outsourcing and Offshoring of Business Services: How Important is ICT? Journal of the European Economic Association 4(2-3): 594-601.

Amit, R., Schoemaker, P. J. H. 1993. Strategic assets and organizational rent. Strategic Management Journal 14(1): 33-46.

Amiti M., Wei S.J. 2009. Service offshoring and productivity: evidence from the US. World Economy, 32: 203-220.

Aron R, Bandyopadhyay S, Jayanty S, Pathak P. 2008. Monitoring process quality in off-shore outsourcing: A model and findings from multi-country survey. Journal of Operation Management 26(2):303-321.

Aron R, Singh J.V. 2005. Getting offshoring right. Harvard Business Review 83: 135-143.

Barney, J. B. 1991. Firm Resources and sustained competitive advantage. Journal of Management 17(1): 99-120.

Bhalla A, Sodhi MS, Son B-G. 2008. Is more IT offshoring better? Journal of Operations Management 26(2): 322-335.

Brouthers, K.D., Brouthers, L.E. 2003. Why Service and Manufacturing Entry Mode Choices Differ: The Influence of Transaction Cost Factors, Risk and Trust. Journal of Management Studies, 40(5), 1179-1204

Bunyaratavej K, Hahn ED, and Doh JP. 2008. Multinational investment and host country development: Location efficiencies for services offshoring. Journal of World Business 43(2):227-242.

Bunyaratavej K., Hahn E.D, Doh, J. 2007. International offshoring of services: A parity study. Journal of International Management 13(1):7-21.

Bustinza O.F., Arias-Aranda D., Gutierrez-Gutierrez L. 2010. Outsourcing, competitive capabilities and performance an empirical study in service firms. International Journal of Production Economics 126(2): 276-288.

Caniato F., Golini R., Luzzini D., Ronchi S. 2010. Towards full integration: eProcurement implementation stages. Benchmarking: an International Journal 17 (4): 491-515.

Contractor F.J., Lorange P. 2002. The growth of alliances in the knowledge-based economy. International Business Review 11: 485-502.

Contractor FJ, Kumar V, Kundu S.K, Pedersen T. 2010. Reconceptualizing the firm in a world outsourcing and offshoring: The organizational and geographical re location of high-value company functions. Journal of Management Studies 47: 1417-1433.

Corbett MF. 2004. The outsourcing revolution: Why it makes sense and how to do it right.

Couto V, Mahadeva M, Lewin A, Peeters C. 2007. The Globalization of White-Collar Work. Booz, Allen, and Hamilton research.

Dahlberg T., Nyrhinen, M. 2006. A New Instrument to Measure the Success of IToutsourcing. In Proceedings of the Hawai'i International Conference on System Sciences, IEEE Computer Society, Kauai.

Deloitte. 2004. It's 2008: Do you know where your talent is? Why acquisition and retention strategies don't work. Deloitte Research. 
Doh JP, Bunyaratavej K, Hahn ED. 2009. Separable but not equal: The location determinants of discrete services offshoring activities. Journal of International Business Studies 40: 926-943.

Doh JP. 2005. Offshore outsourcing: Implications for international business and strategic management theory and practice. Journal of Management Studies 42(3): 695-704.

Dossani R., Kenney M. 2005. Went for Cost, Stayed for Quality? Moving the Back Office to India (Berkeley and Stanford: Mimeo).

Dunning, J. H., Lundan, S. M. 2008. Multinational Enterprises and the Global Economy, 2nd Edition. Cheltenham: Edward Elgar.

Ellram LM, Tate WL, and Billington C. 2008. Offshore outsourcing of professional services: A transaction cost economics perspective. Journal of Operations Management 26 (2):148-163.

Elmuti D. 2003. The perceived impact of outsourcing on organizational performance. MidAmerican Journal of Business 18(2): 49-57.

Farrell D. 2005. Offshoring: value creation through economic change, Journal of Management Studies, 42: 675-683.

Farrell D., Laboissiere, MA., Rosenfeld J. 2006. Sizing the emerging global labor market: rational behavior from both companies and countries can help it work more efficiently. Academy of Management Perspectives, 20: 23-34.

Frohlich, M., \& Westbrook, R. 2001. Arcs of integration: an international study of supply chain strategies. Journal of Operations Management 19(2), 185-200.

Graf M, Mudambi S. 2005. The outsourcing of IT -enabled business processes: a conceptual model of the location decision. Journal of International Management 11: 253-268.

Greene WH. 1997. Econometric Analysis (3rd edn). Prentice-Hall: Upper Saddle River, NJ.

Hahn, E.D., Bunyaratavej, K. 2010. Services cultural alignment in offshoring: The impact of cultural dimensions on offshoring location choices. Journal of Operations Management 28(3), 186-193.

Hätönen J. 2009. Making locational choice. Journal of International Management 15(1): 61-76.

Hätönen J., Eriksson T. 2009. 30+ years of research and practice of outsourcing - exploring the past and anticipating the future, Journal of International Management, 15: 142-155.

Hayes, R.H., Wheelwright, S.C., 1984. Restoring our Competitive Edge Competing through Manufacturing. Wiley, New York, NY.

Heckman J. 1976. The common structure of statistical models of truncation, sample selection, and limited dependent variables and a simple estimator for such models. Annals of Economic and Social Measurement. 5(4): 475-492.

Heckman J. 1979. Sample selection bias as a specification error. Econometrica 47: 153-161.

Holcomb T.R., Hitt M.A. 2007. Toward a model of strategic outsourcing. Journal of Operations Management 25(2): 464-481.

Holweg M., Reichhart A., Hong E. 2011. On risk and cost in global sourcing. International Journal of Production Economics 131(1): 333-341.

Hutzschenreuter T, Lewin AY, Dresel S. 2011. Governance modes for offshoring activities: A comparison of US and German firms. International Business Review 20(3):291-313.

Jahns C, Hartmann E and Bals L. 2006. Offshoring: Dimensions and diffusion of a new business 
concept. Journal of Purchasing and Supply Management 12(4): 218-231.

Jensen PDØ. 2009. A learning perspective on the offshoring of advanced services. Journal of International Management 15(2):181-193.

Jensen, P. D. Ø., Pedersen T. (2011). The economic geography of offshoring: The fit between activities and local context. Journal of Management Studies, 48(2): 352-372.

Karmarkar U. 2004. Will You Survive the Services Revolution? Harvard Business Review 100107

Kedia BL, Mukherjee D. 2009. Understanding offshoring: A research framework based on disintegration, location and externalization advantages. Journal of World Business 44(3): 250261.

Kedia BL., Lahiri S. 2007. International outsourcing of services: a partnership model. Journal of International Management 13: 22-37.

Koh C., Ang S., Straub D.W. 2004. IT Outsourcing Success: A Psychological Contract Perspective, Information Systems Research, 15(4): 356-373.

Kotabe M, Mol MJ, Murray JY. 2009. Global sourcing strategy. In M. Kotabe \& K. Helsen (Eds.), The SAGE handbook of international marketing. London: Sage Publications.

Kotabe M, Omura GS. 1989. Sourcing strategies of European and Japanese multinationals: A comparison. Journal of International Business Studies 20(1): 113-130.

Kotabe, M. 1990. The Relationship between Offshore Sourcing and Innovativeness of U.S. Multinational Firms: An Empirical Investigation, Journal of International Business Studies, 21(4): 623-638.

Kotabe, M. 1992. Global Sourcing Strategy: R\&D, Manufacturing, and Marketing Interfaces, New York: Quorum Books.

Kotabe, M., Murray JY. 2004. Global Procurement of Service Activities by Service Firms, International Marketing Review 21(6): 615-633.

Lee J-N-, Miranda SM., Kim Y-M. 2004. IT Outsourcing Strategies: Universalistic, Contingency, and Configurational Explanations of Success, Information Systems Research, 15(2): 110-131.

Leiblein MJ, Reuer JJ, Dalsace F. 2002. Do make or buy decisions matter? The influence of organizational governance on technological performance. Strategic Management Journal 23: 817-833.

Lewin AY, Massini S, Peeters C. 2009b. Why are companies offshoring innovation?: the emerging global race for talent. Journal of International Business Studies 40(6): 901-925.

Lewin AY, Massini S, Perm-Ajchariyawong N, Sappenfield D, Aird C. 2009a. Is the global outsourcing industry in a for no-holds-barred competition? ORN \& PwC Service Provider Survey Report. Durham: Duke University.

Lewin AY, Peeters C. 2006. The top-line allure of offshoring, Harvard Business Review, 84: 2224.

Lewin AY, Perm-Ajchariyawong N, Russell JW. 2011. Taking Offshoring to the Next Level: The 2009 Offshoring Research Network Corporate Client Survey Report. The Conference Board, Duke University \& Offshoring Research Network. New York: The Conference Board, Inc. 
Lewin AY, Volberda HW. 2011. Co-evolution of global sourcing: The need to understand the underlying mechanisms of firm-decisions of offshore. International Business Review 20: 241251.

Luzzini D., Ronchi S. 2010. Purchasing management in the luxury industry: organization and practices. Operations Management Research 3 (1-2): 7-21.

Luzzini D., Ronchi S. 2011. Organizing the Purchasing Department for Innovation. Operations Management Research 4: 14-27.

Maskell P., Pedersen T., Petersen B., Dick-Nielsen J. 2007. Learning paths to offshore outsourcing: from cost reduction to knowledge seeking, Industry and Innovation, 14: 239-257.

Massini S., Perm-Ajchariyawong N., Lewin A. 2010. Role of corporate-wide offshoring strategy on offshoring drivers, risks and performance. Industry and Innovation 17(4): 337-371.

Mazzola E., Perrone G. 2013. A strategic needs perspective on operations outsourcing and other inter-firm relationships. International Journal of Production Economics, in press, 1-42.

Meade AW, Watson AM, Kroustalis CM. 2007. Assessing Common Methods Bias in Organizational Research. Proceedings of the 22nd Annual Meeting of the Society for Industrial and Organizational Psychology, New York.

Metters R. 2008. A typology of offshoring and outsourcing in electronically transmitted services. Journal of Operations Management 26(2): 198-211.

Mudambi R. 2008. Location, control and innovation in knowledge-intensive industries. Journal of Economic Geography 8: 699-725.

Mudambi, R, Venzin, M. 2010. The Strategic Nexus of Offshoring and Outsourcing Decisions. Journal of Management Studies 47(8): 1510-1533

Murray J.Y., Kotabe M., Wildt A.R. 1995. Strategic and financial performance implications of global sourcing strategy: a contingency analysis. Journal of International Business Studies 26(1): 181-202.

Nordin F. 2008. Linkages between service sourcing decisions and competitive advantage: A review, propositions, and illustrating cases. International Journal of Production Economics, 114(1): 40-55.

Podsakoff PM, MacKenzie SB, Lee JY, Podsakoff NP. 2003 Common Method Biases in Behavioral Research: A Critical Review of the Literature and Recommended Remedies. Journal of Applied Psychology. 88(5):879-903.

Ren, Z. J., \& Zhou, Y. P. 2008. Call Center Outsourcing: Coordinating Staffing Level and Service Quality. Management Science 54(2): 369-383.

Ronchi S. 2001. Collaborative Markets in B2B Relationships. Supply Chain Forum: an International Journal 12 (3): 22-34.

Ronchi S., Brun A., Golini R., Fan X. 2010. What is the value of an IT e-procurement system? Journal of Purchasing and Supply Management 16: 131-140.

Roth, A., Menor, L. 2003. Insights into services research: a research agenda. Production and Operations Management 12 (Summer (2)): 145-164.

Roy, S., Sharma, S., Bhushan, V. 2004. Outsourcing industry in India: Trends, models and policy implications. In Gupta, O.K. (ed.), Managing in a Global Economy: Emerging Challenges to Management Profession. Indian Institute of Management, Calcutta, India 
Roza M, Van den Bosch FAJ, Volberda HW. 2011. Offshoring strategy: Motives, functions, locations, and governance modes of small, medium-sized and large firms. International Business Review 20(3): 314-323.

Schneider, C. O., Bremen, P., Schönsleben, P., \& Alard, R. (2013). Transaction cost economics in global sourcing Assessing regional differences and implications for performance. International Journal of Production Economics 141(1): 243-254.

Stringfellow A, Teagarden M, Nie W. 2008. Invisible costs in offshoring services work. Journal of Operations Management 26(2): 164-179.

Swink, M., Narasimhan, R., \& Wang, C. 2007. Managing beyond the factory walls: Effects of four types of strategic integration on manufacturing plant performance. Journal of Operations Management 25(1), 148-164.

Tate WL, Ellram LM, Bals L, Hartmann E. 2009. Offshore outsourcing of services. An evolutionary perspective. International Journal of Production Economics 120(2): 512-524.

Temouri Y, Driffield NL, Higón DA. 2010. The futures of offshoring FDI in high-tech sectors. Futures 42(9):960-970.

Vivek SD, Richey RG Jr, and Dalela V. 2009. A longitudinal examination of partnership governance in offshoring: A moving target. Journal of World Business 44(1):16-30.

Wang, E. T. G. 2002. Transaction attributes and software outsourcing success: An empirical investigation of transaction costs theory, Information Systems Journal, 12: 121-152.

Williamson OE. 1975. Markets and Hierarchies: Analysis and Antitrust Implications. New York: The Free Press.

Wüllenweber, K., Beimborn, D., Weitzel, T., König, W. 2008. The impact of process standardization on business process outsourcing success. Information Systems Frontier, 10: 211-224

Youngdahl W, Ramaswamy K., Dash K. 2010. Service Offshoring: the evolution of offshore operations. Journal of Operations and Production Management 30(8): 798-820. 